\title{
河川を遡上する津波の 1 次元解析手法の 提案と実現象への適用 \\ DEVELOPMENT OF NUMERICAL MODEL OF TSUNAMI IN RIVER AND ITS APPLICATION TO A PAST EVENT
}

\author{
安田 浩保 ${ }^{1}$ \\ Hiroyasu YASUDA \\ ${ }^{1}$ 正会員 博 (工学) 独立行政法人 北海道開発土木研究所 河川研究室 (₹ 062-8602 札幌市豊平区平岸 1 条 3 丁目)
}

\begin{abstract}
The aim of the paper is to develop a 1-dimensional numerical model of tsunami in river and to apply it to Tokachi-oki earthquake tsunami on September 2003 in Hokkaido, Japan. The computational results of arrival time and water level at each wave gauges agree well with the observed data a high accuracy of less than $10 \%$. Although the actual status of results of field survey is still unknown before the computation, the computational results were explained by the numerical analysis.
\end{abstract}

Key Words : tsunami, undular bore, river, numerical analysis, nonlinear dispersive wave theory, Tokachi-oki earthquake

\section{1.はじめに}

河道内に浸入した津波は波頭部でソリトン分裂と呼 ばれる波数分散現象を生じて波状段波を形成すること がある.このとき，重力加速度に対して水粒子の鉛直方 向加速度が卓越するために水位上昇が引き起こされる。 1986 年の日本海中部沖地震津波 ${ }^{1)}, 2003$ 年の十勝沖地 震津波 ${ }^{2)}$ ， 2004 年のインド洋大津波 ${ }^{3)}$ において，これら が河川に浸入した際にソリトン分裂を発生したことが 知られている.現在のところ，河川に浸入した津波の 波頭部におけるソリトン分裂の特性はもとより，津波 の河川遡上の詳しい挙動は十分に解明されていない .

これまでに河道内に浸入した津波に関する研究は岩 崎ら $^{4)}$, 後藤ら ${ }^{5)}$, 都司ら ${ }^{1)}$ などによって行われている が, KdV-Burgers 方程式を用いた都司らの研究を除き， いずれとも浅水理論に基づいて行われている .このた め, 同現象における波頭部の波状性について十分な議 論がなされるまでには至っていない．しかし，特に河 川工学の立場においては, 波頭部におけるソリトン分 裂および非静水圧とした取り扱いに伴う水位上昇の可 能性や弚の規模について議論することの意義は大きい． 波数分散現象は静水圧の仮定のもとでは現れず，長 波系方程式に基づき解析を行うなら非線形分散波理論 (いわゆる Boussinesq 方程式) を適用しなければなら ない. 安田ら $\left.{ }^{6}\right)$ は急峻な波面形成して流れを遡上する波 状段波の解析においては非線形分散波理論による解析
が合理的かつ不可欠であることを指摘している．弚の 後, 安田ら ${ }^{7)}$ は非線形分散波理論式を支配方程式として 河道内を遡上する津波に関する数值実験を行い, 最長 浸入距離や最大水位と光の出現位置などの基礎的な特 性について言及している．ただし，この方程式系では 浅水理論式と比べると新たに分散項と呼ばれる静水圧 からのズレに対する補正項が加味される．この項を含 めた数値計算は, 物理分散性を取り込んだゆえの計算 の不安定性や陰的解法の必要性ゆえの演算時間増大の 問題を抱えている.

本研究では, 実用的な 1 次元解析手法の開発と, こ の解析手法に基づく 2003 年十勝沖地震津波の河川遡上 の再現計算を行い, 河川に浸入した津波を取り扱う際 の解析手法について議論する .

\section{2. 数理モデル}

(1) 支配方程式

本研究では, 前報7)までと同樣にアーセル数 $U r$ を 1 のオーダーとしたときに ,

$$
\frac{\partial q}{\partial t}+\frac{\partial}{\partial x}\left[\frac{q^{2}}{D}\right]+g D \frac{\partial \eta}{\partial x}=\frac{h^{2}}{3} \frac{\partial^{3} q}{\partial t x^{2}}-\frac{C_{f}}{D^{2}}|q| q
$$

として導かれる積分された Peregrine の式8) を非線形分 散波理論式として適用する。このとき，これに対応す る連続の式は，

$$
\frac{\partial \eta}{\partial t}+\frac{\partial q}{\partial x}=0
$$


である.さらに一般化された河道断面への適用を考え ると，積分された Peregrineの式は分散項の係数に一般 断面における平均的な水深を意味する $R$ を用いて，

$$
\frac{\partial Q}{\partial t}+\frac{\partial}{\partial x}\left[\frac{Q^{2}}{A}\right]+g A \frac{\partial \eta}{\partial x}=\frac{R^{2}}{3} \frac{\partial^{3} Q}{\partial t x^{2}}-\frac{C_{f}}{A D}|Q| Q(3)
$$

のように拡張され，連続の式は，

$$
\frac{\partial \eta}{\partial t}+\frac{1}{B} \frac{\partial Q}{\partial x}=0
$$

のように書き換えられる .ここに $q$ は流量フラックス $t$ は時間座標, $D$ は水深, $x$ は流下方向座標, $\eta$ は水位, $h$ は水深, $C_{f}$ は河床抵抗係数, $Q$ は河川流量, $A$ は流 積， $R$ は径深， $B$ は水面幅である.一方で, 流量フラッ クス表示, 一般断面表示された浅水理論式は光れ光れ 式 (1)，(3)の右辺第 1 項を除いたものである.

河床剪断力から津波が受ける影響に関しては式 (1)， (3) の右辺第 2 項に示したとおり，水深と河床材粒径の 関係から決定される河床抵抗係数を用いた表現を適用 することにした . $C_{f}$ は，

$$
C_{f}=\frac{1}{\phi^{2}}
$$

のように書かれる．ここに, $\phi$ は小規模河床形態に応 じて決定される流速係数である .この $C_{f}$ と頻用される Manning の粗度係数 $n$ との間には等流公式を介して， $n^{2}=C_{f} h^{1 / 3} / g$ の関係がある.

\section{(2) 数值解析法}

Peregrine の式のような非線形分散波理論式は，局所 項のほか分散項においても時間微分項を含むため, 適 切な数值解を得るためには Implicit スキームを用いな ければならない．しかも，物理分散項の作用か顕著な 条件下では, 数值分散項が優勢な打ち切り誤差項を有 する差分スキームを適用するとこの影響も同時に反映 されてくるため，打ち切り誤差特性までを視野に入れ た差分スキームの選定が要求される.計算効率や平面 2 次元計算へ拡張した際の高水敷への乗り上げなどを含 む解析を考えると，Staggered Leap-frog 法と効率的な 陰的演算が可能な Thomas Algorithm を組み合わせた 2 段階混合差分法 ${ }^{9}$ が適当であろう. 本研究では, 前報 と同樣に 2 段階混合差分法を適用することにした .

2 段階混合差分法を式 (3) に適用すると, まず 1 段目 として線形長波理論式が Leap-frog 法により，

$$
\begin{aligned}
& \frac{1}{\Delta t}\left[Q_{i+1 / 2}^{*}-Q_{i+1 / 2}^{j}\right] \\
& +\frac{g D}{\Delta x}\left[\eta_{i+1}^{j+1 / 2}-\eta_{i}^{j+1 / 2}\right]=0
\end{aligned}
$$

のように陽的に解かれ，つぎに 2 段目として移流項と
分散項は三重対角行列に適するように，

$$
\begin{aligned}
& \frac{1}{\Delta t}\left[Q_{i+1 / 2}^{j+1}-Q_{i+1 / 2}^{*}\right] \\
&+\frac{1}{4 \Delta x}[\left\{\left(\frac{Q}{A}\right)_{i+3 / 2}^{j} Q_{i+3 / 2}^{j+1}-\left(\frac{Q}{A}\right)_{i-1 / 2}^{j} Q_{i-1 / 2}^{j+1}\right\} \\
&+\left.\left\{\left(\frac{Q}{A}\right)_{i+3 / 2}^{j} Q_{i+3 / 2}^{j}-\left(\frac{Q}{A}\right)_{i-1 / 2}^{j} Q_{i-1 / 2}^{j}\right\}\right] \\
&=\frac{1}{3}\left(R_{i+1 / 2}^{j}\right)^{2} \frac{1}{\Delta t \Delta x^{2}} \\
& {\left[\left(Q_{i+3 / 2}^{j+1}-2 Q_{i+1 / 2}^{j+1}+Q_{i-1 / 2}^{j+1}\right)\right.} \\
&\left.-\left(Q_{i+3 / 2}^{j}-2 Q_{i+1 / 2}^{j}+Q_{i-1 / 2}^{j}\right)\right]
\end{aligned}
$$

と離散化されて解かれる.ここに， $Q^{*}$ は線形理論から 求められる $Q_{i+1 / 2}^{j+1}$ の中間値， $i, j$ は乥れ光れ空間，時 間に関する離散ステップである .

著者が前報において実施した一樣な河床勾配の河川 に対して河口から滑らかな数学関数を津波として入射 する数值実験では, 移流項を式 (7) に示したように 2 次 精度の中央差分によって離散化した，従って，この場 合の 2 段階混合差分法では , Leap-frog 差分と 2 段目の 移流項の離散化に伴い現れる数值分散性の原因となる 3 階微分項, および分散項の離散化に伴い現れる数值粘 性の原因となる 4 階微分項が主な打ち切り誤差項とし て作用していることになる.このため, 弚のような計 算のもとでは, 適切な空間および時間分割間隔が与え られていれは計算の不安定性への懸念は小さくて済む．

これに対して, 本研究は一般断面の河川を対象とし た計算を念頭においており，津波の入射波の形状や，河 川の縦断方向および横断面形状などの樣々な形状変化 が不必要な高周波成分の発生原因になる。しかし，式 (7)に示したスキームはこのような条件のもとで計算を 実施しなければならないにもかかわらず, 数值粘性が 小さいためにひとたび高周波成分が生じるとこれは減 衰されにくく, 計算領域内に存在し続けてついには決 定的な不安定を生じる .

$2 n$ 階微分項を有する $u(x, t)$ に関する拡散型の偏微分 方程式の理論解が $u=\exp \left[-k^{2 n} \epsilon t\right] \exp [\mathbf{i} k t]$ で与えられ ることを考えれば分かるとおり, 偶数高階の微分項ほ ど高周波成分に対して効果的に作用する.ここで， $\epsilon$ は 拡散係数， $k$ は波数， $\mathrm{i}$ は虚数単位である.つまり，物 理的な分散特性を犠牲にすることなく安定した計算を 実施するためには, 移流項の高精度近似と高周波成分 に対して集中的に作用する偶数高階の打ち切り誤差項 を含む差分スキームを用いればよいことになる．この 条件を満たす有効なスキームの一つして, 主要な打ち 切り誤差項に 4 階微分項を有する 3 次精度風上差分が 考えられる。この場合, 移流項は, 三重対角行列を構 


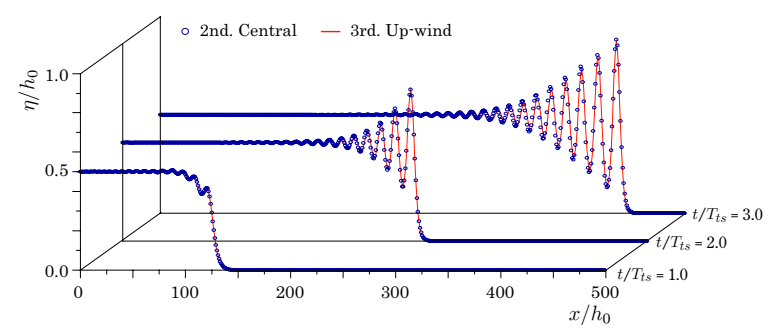

図-1 波数分散現象の数値解析における 2 次精度中央差分と 3 次精度風上差分の精度比較 (3 次精度風上差分は 2 次精 度中央差分に比へ，後続波の位相がごく僅かに遅れるものの， 波頭部に関しては両者は非常に良く一致する.）

成する事を考えれば，

$$
\begin{aligned}
\frac{1}{6 \Delta x}\left[\psi_{1}\right. & \left\{\left(\frac{Q}{A}\right)_{i+5 / 2}^{j} Q_{i+5 / 2}^{j}\right\} \\
+ & \psi_{2}\left\{\left(\frac{Q}{A}\right)_{i+3 / 2}^{j} Q_{i+3 / 2}^{j+1}+\left(\frac{Q}{A}\right)_{i+3 / 2}^{j} Q_{i+3 / 2}^{j}\right\} \\
+ & \psi_{3}\left\{\left(\frac{Q}{A}\right)_{i+1 / 2}^{j} Q_{i+1 / 2}^{j+1}+\left(\frac{Q}{A}\right)_{i+1 / 2}^{j} Q_{i+1 / 2}^{j}\right\} \\
+ & \psi_{4}\left\{\left(\frac{Q}{A}\right)_{i-1 / 2}^{j} Q_{i-1 / 2}^{j+1}+\left(\frac{Q}{A}\right)_{i-1 / 2}^{j} Q_{i-1 / 2}^{j}\right\} \\
+ & \left.\left\{\left(\frac{Q}{A}\right)_{i-3 / 2}^{j} Q_{i-3 / 2}^{j}\right\}\right]
\end{aligned}
$$

のように離散化すればよい .ここに , $\psi_{1} \sim \psi_{5}$ は $Q_{i+1 / 2}^{j}$ の正負に応じて決定される係数である .

ここで, 式 (7)，(8)の両者の特性比較を目的として， 正弦波を $1 / 4$ 周期だけ入射させて兴の後は一定水位と なるように入射条件を与える数值実験を図-1に示すと おり行った . 同図から分かるように , 分散波列の末端 において位相の違いがごく僅かに見られる以外，両者 は非常に良く一致することが分かる．

浅水理論式の計算に関しては，移流項以外に Leapflog 法を適用し，移流項には 1 次精度風上差分を適用 した。

\section{3. 再現計算}

（1）北海道太平洋岸における 2003 年十勝沖地震津波 の河川遡上の概況 ${ }^{2)}$

2003 年 9 月の十勝沖地震に伴い発生した津波は, 少 なくとも北海道の太平洋に面する十勝川, 釧路川, 沙流 川, 鵡川に浸入したことか確認されている。また，波状 段波を形成して十勝川を遡上する津波の樣子が自衛隊 によりビデオ映像として撮影された .これらの河川の平 均的な河床勾配は光れ枈れ $1 / 5,000 ， 1 / 7,500 ， 1 / 750$ ， 1/1,000 程度である。

十勝川では河口からの流心距離にして約 $9.5 \mathrm{~km}$ の地 点, 釧路川では断面幅が急縮する河口からおよ光 $8 \mathrm{~km}$ の地点において津波浸入を示す明瞭な水位変動が観測

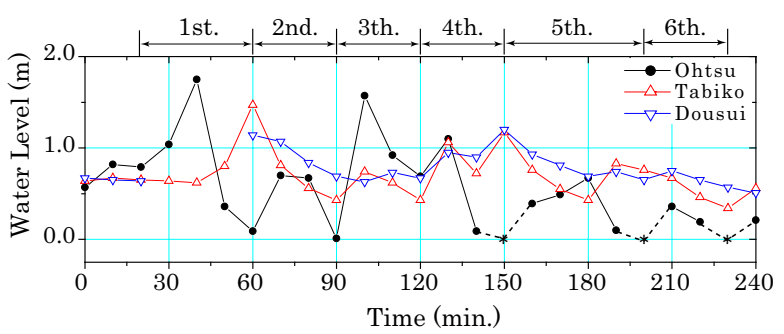

図-2 地震発生 4 時間後までの 10 分間隔水位記録 (黑線で示 した大津観測所の記録は $0 \mathrm{~m}$ 以下の水位が欠測だったために *で示したように補完している .)

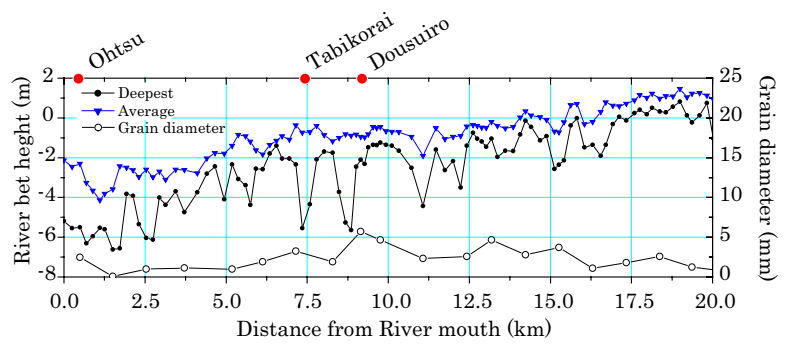

図-3 十勝川の縦断形状と平均粒径の縦断分布

された .一方，前述の二つの河川に比べて河床勾配が 急な鵡川や沙流川においても，河口に最も近い水位観 測所で聿波と考えられる水位変動が観測された .

本研究では, 前章までに述べた解析手法に基づき，こ れらの河川うち，十勝川における津波の遡上に関する 再現計算を実施した．図-2 は, 津波の通過を示す顕著 な水位変動が観測された大津, 旅来, 導水路水位観測 所の地震発生から 4 時間後までの 10 分間隔で記録され た水位の時間波形である .この地震により生じた津波 は，地震発生から 4 時間の間に 6 波の津波が十勝川の 河口に到達し，ここに到達した時点の周期は 30〜 40 分 程度であった . 乥れらは, 河口に到達した時点の波高 にもよるが大津から旅来までの $7 \mathrm{~km}$ ほどを 20 分程度 で遡上していた。

なお，大津，旅来，導水路観測所の水位計はいずれ とも，風波などによる $2 \mathrm{~cm}$ 程度の水位变動を検出可能 な感度を有し， 1 秒毎に水位を取得して光の 15 秒間平 均值を 10 分間隔で出力している.ただし，これらの観 測値は，各時刻毎の值の信頼度は高いものの，観測間 隔の問題で実現象の連続的な波形形状 (例えば，波形勾 配)を十分に表現し得ていない可能性を考慮に入れたう えで取り扱わなければならない .

\section{(2) 河道形状}

本研究では解析対象区間を河口から流心追加距離で $20 \mathrm{~km}$ までとした .ただし，湾曲部などの影響で管理用 の距離標 $\mathrm{kp}$ と流心間距離との間に大きな差異が見られ る断面が存在することから，本文中における縱断距離 はすべて流心間追加距離を用いた表記としている .こ の区間の十勝川の縦断形状の概略は，図-3に示したと おり，平均的な河床勾配はおよ光 $1 / 5000 ，$ この間の 河床材の粒径は 1 6 $6 \mathrm{~mm}$ 程度である. 大津, 旅来, 導 水路水位観測所の縦断的な位置関係は, 同図の上部枠 
外に示したとおりである .一方で, 対象区間内の横断 面形状は堤防間距離はおよ关 $1000 \mathrm{~m}$ ，低水路幅はおよ 光 $300 \mathrm{~m}$ である。

なお，式 (3) の右辺第 1 項の分散項の係数に径深 $R$ を導入している. $500 \mathrm{~m}^{3} / \mathrm{s}$ ずつ流量を増加させる不等 流計算を行ったところ，いずれの流量においても $R$ と 平均水深は良好な一致を示した. 従って, この項の計 算で $R$ を適用することは妥当であると考えられる．

\section{(3) 初期条件}

a) 河床形態の推定

一般に小規模河床形態の推定は，無次元掃流力 $\tau_{*}$ と 流速係数 $\phi$ の関係に基づき行われる .これを対象区間 に適用した結果，対象区間は移動の少ない平坦河床にお おむね分類された .このとき, 流速係数は, Engelund $\&$ Hansen $^{10)}$ が示した $\phi=6+2.5 \ln \left(\frac{D}{2.5 d_{s}}\right)$ を用いて いる.ここで, $d_{s}$ は河床材の平均粒径である．

b) 初期流量の推定

初期流量は, 地震発生時刻における旅来, 導水路, 茂岩水位観測所の水位が最も適切に再現されるように $20 \mathrm{~m}^{3} / \mathrm{s}$ ずつ流量を増加させる不等流計算を行うことに より推定した . 弚の結果, 流量を $220 \mathrm{~m}^{3} / \mathrm{s}$ としたとき に最も各観測地点の值と計算值が良く一致した .なお， この不等流計算では, 下流端水位に地震発生時刻の大 津観測所での水位を与えて行った .

\section{（4）境界条件}

上流端の境界条件は次のように与えることにした .十 勝川流域の複数地点の降雨記録を調べたところ, 地震 の前後 24 時間における当該流域の降雨はあつたもの の, 弚の累積雨量はたかだか $30 \mathrm{~mm}$ 程度と小さく，河 川の流量への影響は小さいと考えられる. 従って, 上 流端から供給される流量は定常状態とし, 前項で求め た $220 \mathrm{~m}^{3} / \mathrm{s}$ を与えることにした 。

つぎに，下流端の境界条件は，図-2の黑実線で示し た 10 分間隔で観測された大津水位観測所の水位記録を $\Delta t$ に応じた内挿補間を行ったうえで与えた．光のよう にしたのは，まず，大津水位観測所は河口からおよ光 $0.7 \mathrm{~km}$ の地点にあり, しかも不等流計算の結果, 解析 対象区間のうち河口付近の水面勾配は非常に小さかっ た . 光のうえ, 十勝川の河口には大津漁港が存在して 潮位観測を行っているものの, 津波浸入時の記録は欠 測となっていたためである .

\section{(5) 計算条件}

再現計算は, 明瞭な゙津波の浸入か確認できた地震発生 から 4 時間後までを対象に実施した . 空間離散間隔 $\Delta x$ はエリアジング誤差の回避と分散波列の十分な解像を 考え $2 \mathrm{~m}$ とし，時間離散間隔 $\Delta t$ は浅水理論式では 0.02 秒, 非線形分散波理論式では 0.0002 秒と設定した .

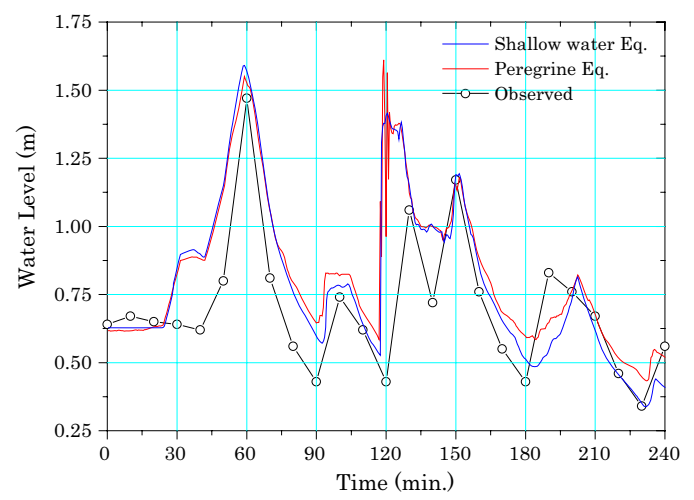

(a) 旅来水位観測所 (流心距離 $7.5 \mathrm{~km}, \mathrm{kp} 9.3$ )

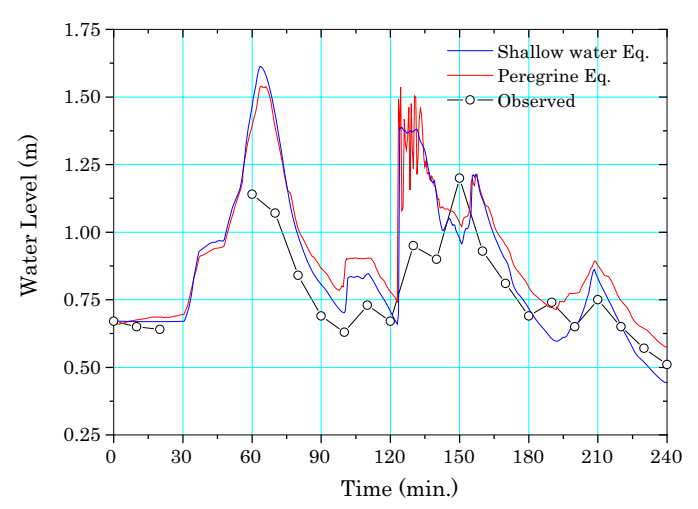

(b) 導水路水位観測所（流心距離 $9.0 \mathrm{~km}, \mathrm{kp} 10.8$ )

図-4 10 分間隔水位記録と再現計算結果との比較 (観測値と計 算值の同時刻データを比較し, 光の較差を再現時間内で平均 すると浅水理論式では $10 \%$ 弱, 非線形分散理論式では $15 \%$ 程 度の過大評価の傾向にある.)

\section{(6) 再現計算の妥当性と考察}

実施した再現計算の妥当性を確認するため, 観測値 と浅水理論式，および非線形分散波理論式に基づく数 值計算の結果との比較を行った . 図-4 (a)，(b)に示す とおり，いずれの支配方程式による再現計算ともに各 観測地点での津波の到達時刻は良好に再現されている と言えよう．水位に関しては観測值に対し計算值が若 干過大となる傾向にあるものの概ね再現された . また， 非線形分散波理論式に基づく計算から，第 3 波だけが 明瞭な波状段波を形成していたことが明らかになった .

第 1 波，第 3 波に関しては水位記録と計算値のあい だで一部差異が見られた .これらの理由は光れ次 のように考えられる .

第 3 波では地震発生から 130 分後の水位記録が旅来， 導水路ともに計算値との差異が最も大きいが，これは 非線形分散波理論式の計算結果に着目すると光の理由 を次のように推測することができる．この計算結果よ ると波頭部に波数分散現象を伴う津波が両地点を通過 していたことが図-5から見て取れる.つまり，第 3 波 は波状段波となって光れぞれの観測地点を通過したた め, 水位計は波状段波の水位が小さい側に振れた時点 を捉えていたものと推察することができる .これに対 し, 浅水理論式は波数分散現象を表現し得ない (波頭 部で見られる波数分散現象は打ち切り誤差によるもの) 


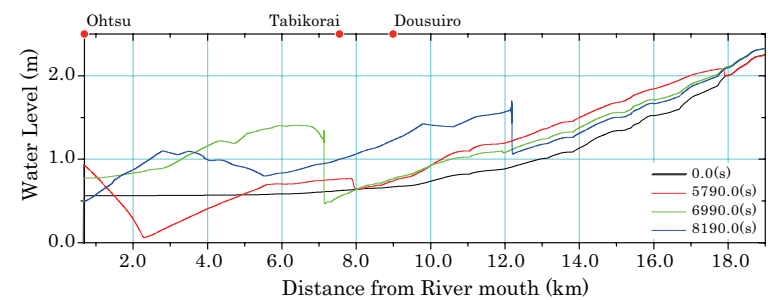

(a) 浅水理論式

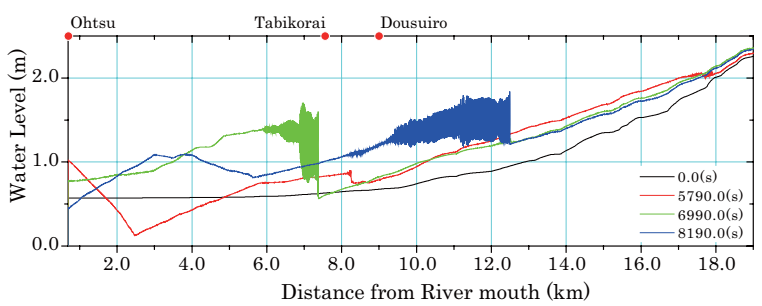

(b) 非線形分散波理論式 (移流項は 2 次精度中央差分)

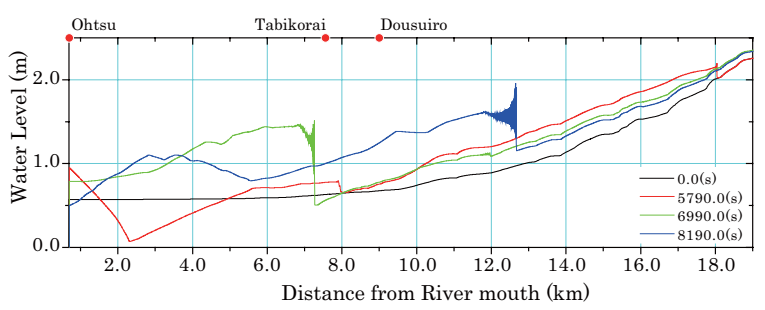

（c）非線形分散波理論式 (移流項は 3 次精度風上差分)

図-5 第 3 波の 30 分ごとの空間波形

から，この計算結果と水位記録を比較すると両者には 大きな差異が見られる結果となる .

第 1 波の計算値に関しては，これの水位上昇部と降 下部において $0.20 \mathrm{~m}$ 程度の過大評価が見られたものの， 現在のところ , この原因の特定には至っていない .

a) 空間波形

前述したとおり，今回の再現計算のうち，顕著な波 数分散現象を生じていたと推測されるのは第 3 波であ る.この第 3 波に関する 30 分毎の空間波形を図-5 (a) 〜 (c) に示した . 同図 (a) は浅水理論式, 同図 (b) は移 流項を 2 次精度中央差分で離散化した非線形分散波理 論式, 同図 (c) は移流項を 3 次精度風上差分て離散化し た非線形分散波理論式に基づく数值計算の結果として 得られた空間波形である .

同図 (a)の $t=6990,8190$ 秒の波形はともに波頭部 で波数分散現象を生じているように見える.しかし，こ れは 1 次精度風上差分に伴う数值粘性より減衰するこ とのなかった Leap-frog 法の数值分散性に起因して現 れた高周波成分 (いわゆる数值ギブス振動) であると 考えられる .

前者に対して同図 (b) , (c) ではともに $t=6990,8190$ 秒の波形において波頭部から離れるに従って振幅が小 さくなる波数分散現象を認めることができる．この波 数分散現象は, 津波が上流に向かって遡上するに従って 弚の区間長が次第に延長されていく.ただし，現在の ところ, 著者は波数分散現象を生じる区間長やソリト ン分裂波列の砕波限界について十分な知見を持ち合わ

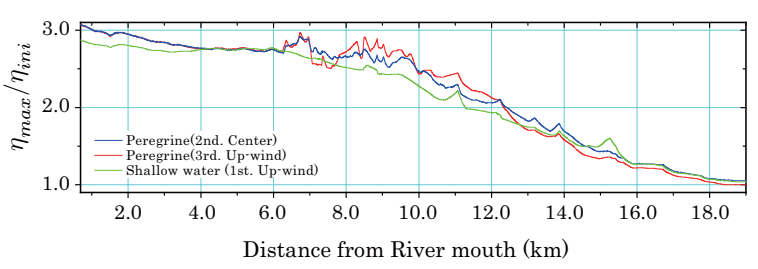

(a) 最大水位上昇率

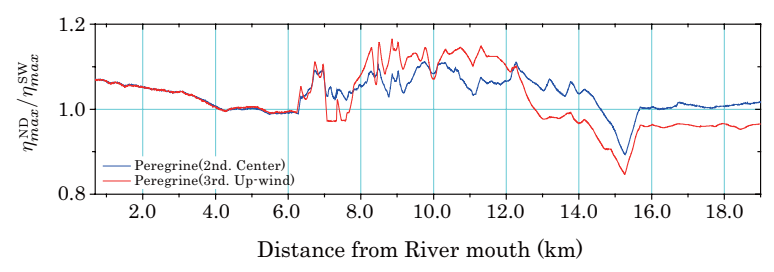

(b) 波数分散現象に伴う水位上昇率

図-6 最大水位上昇率と波数分散現象の出現区間 せておらず，(b)，(c)のいずれが物理的に妥当であるか を判断することはできない．しかし，図-1に示した理 想的な条件下における波数分散現象に関する数值実験 では両者の差はほとんどないうえ， 3 次精度風上差分を 用いた場合の方が数值分散項の介入をより抑制できる から，(c)の結果には物理分散項の効果のみが適切に反 映されていると考えられよう .

b) 最大水位上昇率と波数分散現象の出現区間

津波が河川に浸入したことに伴う各地点における水 位の最大変化率，および波数分散現象のみによる水位

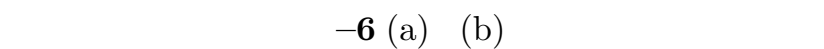
同図 (a) 中の $\eta_{i n i}$ は初期水位 . $\eta_{\max }$ は最大水位, 同図 (b) 中の $\eta_{\max }^{\mathrm{ND}}$ は非線形分散波理論式の計算值から得た 最大水位 . $\eta_{\text {max }}^{\mathrm{SW}}$ は浅水理論式により得たものである.

まず，同図 (a) によると，河口からおよ光 $6 \mathrm{~km}$ 程度 までは津波波高の減衰率は光れほど大きくないものの， この地点を過ぎると次第に減衰率が大きくなっていた ことが分かる．また，この図では浅水理論式と非線形 分散波理論式の両者について示しているが，このうち 後者に着目すると, 河口からおよ光 $6 \mathrm{~km}$ 上流の地点に 到達以降から顕著な波数分散現象を生じていたことが 分かる.しかも，波数分散現象による高波数の振幅は 次第に減衰していくものの, 弚れは河口から $15 \mathrm{~km}$ 以 上上流にまで維持されていた .

つぎに，同図 (b) を見れば分かるとおり，いずれの差 分スキームを用いた場合でも少なくとも $10 \%$ 以上，数 值分散項の介入が小さい 3 次精度風上差分を用いた場 合では $15 \%$ 程度の波数分散現象に伴う水位上昇力数 $\mathrm{km}$ にわたり生じていたことが分かる .

\section{（7）再現計算結果に基づく実現象の考察}

a) 高水敷への乗り上げ

安田らはこの津波の河川遡上に関する痕跡調査と水 位記録の分析を行い，この津波の高水敷への到達の可 能性について議論している ${ }^{2)}$. 図 -7 は最大水位の包絡 線と高水敷高さの関係を示したものである .この図に 


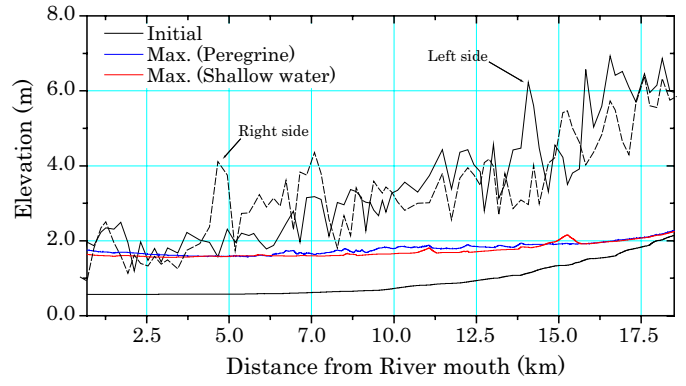

図-7 最大水位と高水敷高さの関係

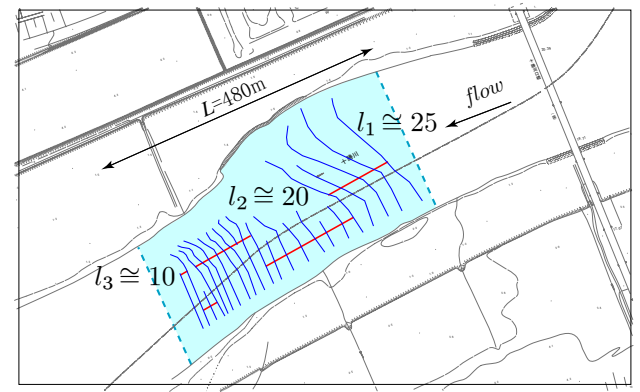

図-8 十勝川で撮影されたソリトン波列の波長

よると，少なくとも河口から $3.7 \mathrm{~km}(\mathrm{kp} 6.0)$ までの右 岸高水敷，および左岸高水敷の一部が冠水していた可 能性が非常に高い .この結果は, kp5.7 右岸付近の上流 向きでの植生倒伏 , および $\mathrm{kp} 7.5$ 左岸のものを除く痕 跡調査で得られた結果と良く一致する。

b) 計算結果と撮影されたビデオ映像との照合

波状段波を形成して十勝川を遡上する映像が自衛隊 によって地震発生からおよ乥 100 分後に河口から約 $3.2 \mathrm{~km}(\mathrm{kp} 5.7)$ ほど上流の地点で撮影された . 図-4 どから分かるとおりこれは第 3 波である.一方，数值 解析の結果では, 第 3 波の前傾化が急進して波状段波 を形成しはじめるのは, 地震発生から 108 分後ころに 河口から $5.0 \mathrm{~km}$ の地点付近においてである . この差異 については次のように解釈することができよう . 大津 を通過した実際の第 3 波は光こで観測された形状より 幾分波形勾配が急峻であったにもかかわらず, 10 分間 隔の観測ゆえに観測值には光れが顕れなかったものと 考えられる．つまり，境界条件として用いた大津での 水位記録の波形勾配は結果として実現象よりも緩やか なため, 計算値では実現象よりも上流側で波状段波を 形成することになったものと推測できる .

この他，この撮影されたソリトン波列の波長を図-8 に示すとおり測定した .ここでは，最も鮮明に津波を 捉えているーコマを選び, 光こから津波の波峰を同図

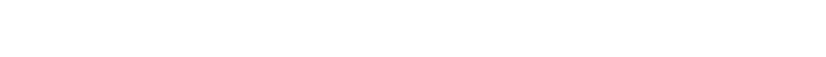
波峰間の距離を赤線上で測定している. 弚の結果, 最

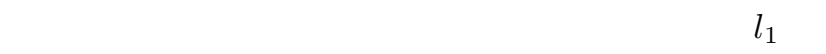
多少ばらつきがあるものの $25 \mathrm{~m}$ 程度， $l_{2}$ は $20 \mathrm{~m}$ 程度， $l_{3}$ は $10 \mathrm{~m}$ 程度であった . 前述の通り, 計算におけるソ リトン波列の出現位置は撮影映像と比べ上流に位置し
ていたものの，図中の波峰間距離の測定值と計算值の 弚れを比較したところ，両者は良く一致していた。た だし, 今回適用した非線形分散波理論式による得られ たソリトン素波の妥当性についてさらに検討を進める 余地か残されている.

\section{4. おわりに}

河川を遡上する津波の 1 次元解析法を提案し，これ を実現象に適用して妥当性を確認した。弚の結果，簡 便な解析法でありながら計算值と実測值は，到達時間， 最大水位などさまざまな諸量ともに良好に一致した . ま た，詳細な部分において多少の疑義があるものの，波 数分散現象に伴う水位上昇が長距離区間にわたり無視 し得ない規模で生じることが明らかとなった . 同現象 の数值解析にあたっては支配方程式に非線形分散波理 論式を適用すべきであるとともに, 光の数値計算は演 算効率とともに打ち切り誤差の特性を慎重に見定めた うえで行わなければならない，今後は，同現象が鋭い 湾曲部や中規模河床形態から受ける影響, および有限 振幅性が大きい場合における検討を継続的に実施して いく必要がある .

謝辞：本研究は国土交通省北海道開発局, 同省同局 帯広開発建設部からの支援を受けて実施されるととも， 水位記録, 河道形状データなどの貴重な資料を提供し て頂いた 、ここに記して謝意を表します。

\section{参考文献}

1) Tsuji, Y. and Yanuma, T. and Murata, I. and Fujiwara, C.: Tsunami Ascending in Rivers as an Undular Bore, Natural Hazards 4, pp.257-266, 1991.

2) 安田 浩保, 渡邊 康玄, 藤間 功司 : 2003 年 9 月の十勝 沖地震に伴い発生した津波の河川溯上, 土木学会論文集， No.768/II-68, pp.209-218, 2004.

3) 田中 仁, 中川一, 石野和男, 矢野真一郎, Bandara Nawarathna, 安田 浩保, 渡邊康玄, 長谷川和義: スマ トラ沖地震津波によるスリランカでの被害に関する現 地調査-河川被害を中心として-, 水工学論文集, Vol.50, 2006 (投稿中)

4) 岩崎 敏夫, 阿部 至雄, 橋本 潔: 河川津波の特性に関する 研究, 第 24 回海岸工学講演会論文集, pp.74-77, 1977.

5) 後藤 智明, 首藤 伸夫 : 河川津波の遡上計算, 第 28 回海 岸工学講演会論文集, pp.64-68, 1981.

6) 安田 浩保, 山田 正, 後藤 智明: スルースゲートの閉鎖に 伴い発生する段波の水理実験と乥の数値計算, 土木学会 論文集, No.733/II-63, pp.89-105, 2003.

7) 安田 浩保, 渡邊 康玄: 河川を遡上する津波に関する数值 的研究, 水工学論文集, Vol.49, pp.1327-1332, 2005.

8) Peregrine, D.H. : Long waves on a beach, J. Fluid Mech., Vol.27, pp.815-827, 1967.

9）たとえば，後藤 智明：2 段階混合差分法を用いた線形分 散波方程式の数値計算における打ち切り誤差, 津波工学 研究報告, 第 20 号, pp.13-22, 2003.

10) Engelund \& Hansen : A Monograph on Sediment Transport in Alluvial Stream, Teknisk Forlag, Copenhagen, Denmark, 62p., 1967.

(2005. 9. 30 受付) 